\title{
Efek Washback Ujian Nasional Subyek Bahasa Inggris Pada Tingkat Sekolah Menengah Pertama (SMP) di Indonesia
}

\author{
M. Arif Rahman Hakim \\ Institut Agama Islam Negeri (IAIN) Bengkulu \\ arifelsiradj@iainbengkulu.ac.id \\ Andri Saputra \\ Institut Agama Islam Negeri (IAIN) Bengkulu \\ andrisaputraozz@gmail.com
}

\begin{abstract}
A National Examination is commonly known as a standardised test held by a country, such as Indonesia, to gange the students' competence and the quality of their schools. Many people argue that the national examination implementation is likely to have positive and negative effects, not only on students but also on schools. This study aims to investigate the positive and negative effects of the National Examination of English subject in Indonesian junior high schools concerning English teachers' classroom teaching and students' learning. This study used a narrative literature review study, which reviews critiques and summarizes the literature body and draws conclusions regarding the topic question. By examining literature available and the authors' experiences in doing the national examination as the participant and preparing students to face the examination, this paper showed that the National Examination of English emerges to have more negative impacts than positive ones. The result of this paper presents the authors' recommendation to be used by key stakeholders in Indonesia that they should re-design the national examination to measure the students' border competence effectively and objectively in English subject.
\end{abstract}

Keywords : Washback Effect; National Examination; English Subject; Junior High School.

\begin{abstract}
Abstrak : Ujian Nasional umumnya dikenal sebagai tes standar yang diadakan oleh suatu negara, seperti Indonesia, yang bertujuan untuk mengukur kompetensi siswa dan kualitas sekolah. Kebanyakan orang berpendapat bahwa pelaksanaan ujian nasional cenderung memiliki efek positif dan negatif, tidak hanya pada siswa tetapi juga pada sekolah yang bersangkutan. Tujuan dibuatnya artikel ini adalah untuk menyelidiki efek positif dan negatif dari pelaksanaan Ujian Nasional mata pelajaran Bahasa Inggris di tingkat sekolah menengah pertama (SMP) di Indonesia yang berfokus kepada proses belajar mengajar antara guru dan siswa dikelas. Penelitian ini menggunakan studi tinjauan literatur naratif yang meninjau kritik dan merangkum literatur utama lalu diakhiri dengan menarik kesimpulan terkait pertanyaan topik. Dengan memeriksa literatur yang tersedia dan pengalaman penulis dalam mengikuti ujian nasional baiik itu sebagai peserta maupun mempersiapkan siswa untuk menghadapi ujian, hasil kajian dalam artikel ini menunjukkan bahwa Ujian Nasional Bahasa Inggris memiliki lebih banyak dampak negatif dibandingkan dengan dampak positifnya. Hasil dari kajian ini mendapatkan rekomendasi penulis yang nantinya dapat digunakan oleh para pengambil kebijakan terkait di Indonesia bahwa mereka harus merancang ulang model ujian nasional dari yang sudah ada untuk mengukur batas kompetensi siswa secara efektif dan objektif dalam subyek Bahasa Inggris.
\end{abstract}

Kata Kunci : Efek Washback; Ujian Nasional; Bahasa Inggris;

Sekolah Menengah Pertama (SMP).

\section{Pendahuluan}

Ujian nasional merupakan ujian standar resmi yang diadakan oleh Negara Indonesia dengan tujuan umum yaitu untuk mengukur kemampuan siswanya. Setiap tahunnya, ujian nasional memang seringkali menjadi suatu hal 
yang meresahkan baik itu bagi guru, siswa, maupun orang tua. Satu hal yang menjadikan pelaksanaan ujian nasional selalu bermasalah selama ini, dikarenakan ujian nasional dijadikan salah satu syarat kelulusan bagi siswa (Hadi, 2014). Banyak orang berpendapat bahwa pelaksanaan ujian nasional cenderung memiliki dampak positif dan negatif pada siswa, sekolah, dan beberapa pihak terkait. Dalam kajian ilmu linguistik, istilah yang paling umum digunakan untuk menggambarkan dampak pengujian tersebut adalah washback (Cheng \& Curtis, 2012). Washback secara luas didefinisikan sebagai pengaruh pengujian terhadap pengajaran dan pembelajaran (Brown, 2004; Cheng \& Curtis, 2004; Cheng, 2005; Fulcher \& Davidson, 2007). Selanjutnya, Brown (2005) menambahkan bahwa definisi washback mencakup efek tes pada pengajaran dan pembelajaran di kelas secara khusus. Untuk lebih jauh menguraikan pemahaman tentang washback, Shohamy dalam Tsagary (2007) merangkum empat definisi utama dari konsep ini. Pertama, washback mengacu pada dampak tes terhadap pengajaran dan pembelajaran. Kedua, ini adalah instruksi yang didorong oleh pengukuran, terkait dengan gagasan bahwa tes harus mendorong pembelajaran. Ketiga, penyelarasan kurikulum berfokus pada hubungan antara pengujian dan pembelajaran. Terakhir, validitas sistemik menekankan integrasi tes ke dalam sistem pendidikan dan kebutuhan untuk menunjukkan bagaimana pengenalan pengujian dapat meningkatkan pembelajaran.

Seperti disebutkan di atas, terdapat dua jenis washback, yaitu yang menghasilkan efek positif dan negatif. Menurut Cheng dan Curtis (2012), washback negatif menghasilkan efek yang tidak diinginkan atau tidak nyaman pada pengajaran dan pembelajaran untuk tes tertentu, yang mana menghasilkan tes yang buruk serta menilai area yang tidak ingin ditutupi oleh guru atau peserta didik. Hal itu juga dapat diindikasikan sebagai ketidakcocokan antara konten pembelajaran dan tes itu sendiri. Sedangkan untuk washback positif, di sisi lain, mengacu pada kemampuan uji prosedur untuk mendorong praktik pengajaran yang baik (Alderson \& Wall dalam Cheng dan Andy, 2012). Menurut Cheng dan Curtis (2004), efek washback dari sebuah tes akan menghasilkan efek negatif jika merujuk kembali ke prinsip-prinsip pembelajaran dan tujuan pembelajaran yang terlihat terkait, tetapi akan menjadi positif jika efeknya berguna dan mendorong seluruh rentang perubahan yang diinginkan. Karena itu, akan muncul anggapan bahwa sebuah ujian dapat dikatakan gagal atau buruk jika terdapat ketidaksesuaian antara materi yang telah diajarkan dan dipelajari dengan soal yang diujikan. Selain pengaruh negatif, ujian nasional juga dapat menimbulkan efek positif yang membuat para guru dan orang tua lebih memperhatikan para siswa pada saat menjelang waktu pelaksanaan ujian nasional, terutama bagi mereka yang memiliki masalah belajar (Furaidah, Ali dan Utami, 2018).

Para penulis telah merasakan pengalaman melaksanakan Ujian Nasional (UN) baik sebagai siswa yang secara langsung merasakan ketegangan UN dan 
juga sebagai guru yang berjuang untuk membantu para siswa agar dapat lulus ujian. Sistem ini kemungkinan dapat memberikan efek washback yang positif sekaligus efek negatif pada kelas bahasa Inggris di sekolah menengah pertama. Ketika penulis menghadapi UN sebagai siswa, masalah yang dihadapi adalah ketakutan secara psikologis, terutama dalam mata pelajaran bahasa Inggris. Salah satu alasannya adalah bahwa setiap tahun skor standar minimum kelulusan selalu meningkat. Secara praktis, ini dapat berarti menjadi sebuah tantangan, karena disisi lainnya kualitas dan fasilitas sekolah serta standar pengajaran tidak ikut ditingkatkan.

Kondisi seperti yang telah disebutkan diatas akhirnya membuat para siswa lebih berupaya menemukan sumber pengajaran alternatif, seperti yang tersedia di pusat pembelajaran, dengan tujuan untuk memperoleh jam tambahan belajar dengan harapan dapat lulus ujian nasional nantinya. Namun faktanya, tidak semua siswa mampu memiliki kelas tambahan karena tingginya biaya yang dikeluarkan. Akibatnya, para siswa yang berasal dari latar belakang ekonomi dibawah rata- rata tidak mempunyai pilihan lain selain mengandalkan proses belajar mengajar disekolah mereka. Skenario seperti ini kemungkinan besar yang membuat beberapa siswa tersebut merasa lebih cemas dalam menghadapi Ujian Nasional. Ketika penulis masih berstatus sebagai pelajar ditingkat SMA, pelajaran Bahasa Inggris terasa begitu sangat sulit. Hal tersebut juga dirasakan oleh sebagian besar rekan sekelas penulis dimasa itu. Mereka merasa bahwa soalsoal pada ujian nasional pelajaran Bahasa Inggris sangat sulit bagi mereka, persoalan ini juga kemungkinan disebabkan oleh kondisi dan status sekolah yang terletak didaerah yang memiliki fasilitas terbatas dan kekurangan guru yang benar- benar kompeten. Mereka merasa bahwa kosakata yang seringkali muncul pada soal ujian nasional terlalu tinggi dan pertanyaan - pertanyaan yang diberikan kepada mereka dalam ujian nasional tidak sepenuhnya berhubungan dengan apa yang telah mereka pelajari. Oleh karena itu, untuk memberikan semua siswa kesempatan terbaik untuk meningkatkan prestasi, tampaknya masuk akal untuk menyarankan bahwa harus ada peningkatan dalam hal metodologi pengajaran bagi para guru yang mengajar di kelas, karena hal ini dinilai akan mengimbangi kenaikan skor kelulusan minimum yang terjadi disetiap tahunnya.

Namun di sisi lain, sistem ini seringkali juga dapat memicu para siswa untuk belajar dengan lebih serius dan mereka menunjukkan kemauan serta motivasi dalam kelas persiapan ujian nasional (Effendi, dan Ichwan, 2016). Penulis memperhatikan kelas yang akan menghadapi Ujian Nasional ini dan membandingkannya dengan saat penulis mengajar para siswa ini saat mereka masih duduk dikelas VII dan VIII di mana para siswa lebih sulit untuk mempelajari mata pelajaran Bahasa Inggris yang kemungkinan besar juga disebabkan karena kurangnya motivasi. Oleh karena itu, berdasarkan hasil 
diskusi diatas, ujian nasional juga dapat memberikan efek positif dalam hal ini. Secara umumnya, terdapat beberapa kontra terkait ujian nasional mata pelajaran Bahasa Inggris, dan karenanya banyak beberapa pihak yang merasa keberatan dengan keberadaannya. Namun, menurut pandangan yang berlawanan, ujian nasional juga tampaknya memberikan beberapa manfaat positif, seperti mendorong siswa untuk belajar dengan lebih serius.

Lebih lanjutnya didalam artikel ini, penulis akan membahas lebih jauh terkait efek positif dan negatif dari Ujian Nasional mata pelajaran Bahasa Inggris di tingkat sekolah menengah pertama (SMP) di Indonesia melalui kajian tinjauan literatur naratif yang bertujuan untuk meninjau kritik dan merangkum isi literatur, lalu menarik kesimpulan tentang pertanyaan topik utama (Cronin, Frances dan Michael, 2008).

\section{Tinjauan Pustaka}

Menurut Sundayana, Meekaeo, Purnawarman, and Sukyadi (2018) Ujian Nasional adalah sebuah penilaian pendidikan standar untuk sekolah dasar dan sekolah dasar pendidikan menengah di Indonesia yang dikelola langsung oleh Badan Standar Nasional Pendidikan (BSNP) dan berdasarkan Peraturan Pemerintah No. 75 tahun 2009, dijadikan standar kelulusan (Anggraeni, 2015). Terkait proses pelaksanaannya, Sukyadi dan Mardiani (2011) menjelaskan bahwa Indonesia telah menyelenggarakan ujian nasional untuk siswa sejak tahun 2005 (Peraturan Pemerintah nomor 19 tahun 2005).

Ujian nasional ini melibatkan para siswa yang telah menduduki kelas enam sekolah dasar, kelas Sembilan sekolah menengah pertama, dan kelas dua belas sekolah menengah atas sebagai syarat kelulusan minimum (Sundana, 2018).

Dalam Peraturan Menteri Pendidikan dan Kebudayaan Nomor 144 Tahun 2014 disebutkan bahwa Ujian Nasional merupakan kegiatan pengukuran serta penilaian pencapaian standar kompetensi lulusan secara nasional pada beberapa mata pelajaran tertentu (Alawiyah, 2015). Evaluasi yang dimaksud terdiri dari dua konsep, yaitu: evaluasi sebagai suatu proses yang terdiri dari rangkaian kegiatan penilaian dan evaluasi sebagai tindakan untuk menunjukkan kualitas dari hasil penilaian tersebut (Sanjaya, 2008). Secara umumnya tujuan sebuah evaluasi biasanya untuk menilai sejauh mana tingkat keefektifan kebijakan publik guna dipertanggungjawabkan kepada konstituennya (Nugroho, 2011). Sehingga Alawiyah (2015) berpendapat jika dikaitkan dengan sistem pendidikan, evaluasi bertujuan untuk mendapatkan informasi yang akurat mengenai tingkat pencapaian dari tujuan pembelajaran oleh siswa, sehingga nantinya tindak lanjutnya dapat diupayakan. Daryanto (2007) juga menyatakan bahwa tindak lanjut tersebut dapat berupa penempatan pada tempat yang tepat, pemberian umpan balik, diagnosis kesulitan belajar siswa, dan penentuan kelulusan. 
Jika dikaji secara dampaknya, terdapat sejumlah dampak positif yang dibawa oleh ujian nasional. Misalnya, ujian nasional menyebabkan tingkat positif homogenitas nasional dalam standar pendidikan dan praktik (National Research Council, 2002). Rind, Mumtaz dan Mohammad (2019) juga berpendapat ujian nasional dapat menjadi indikator prestasi yang sangat penting untuk keberhasilan siswa dalam studi lebih lanjut karena sistem ujiannya berpeluang untuk memberikan perbandingan yang adil di berbagai sekolah. Namun sebaliknya jika penilaian siswa hanya tergantung pada sekolah secara otonom, hal itu dapat menyebabkan akuntabilitas hukum untuk nilai yang diberikan oleh guru dan dapat menimbulkan distorsi karena tekanan yang berasal dari para orang tua atau terkait kompetisi antar sekolah (Rind, Mumtaz dan Mohammad, 2019). Studi lebih lanjut yang dilakukan oleh Pizzaro (2009) dan Spatt (2005) menggambarkan secara rinci bahwa kurikulum, bahan, sikap, strategi pembelajaran dan pengajaran, perasaan dan konten pengajaran semuanya dipengaruhi oleh tes tertentu. Tes, dalam hal ini Bahasa Inggris, sebagai penilaian tinggi dapat menyebabkan fokus yang lebih besar pada pengajaran, dan akan memberikan para siswa dan guru tujuan khusus untuk ditargetkan. Agaknya, ini bisa berfungsi sebagai faktor pendorong bagi siswa dan guru. Keinginan untuk menghindari kegagalan mencapai skor target dapat mendorong para siswa untuk belajar lebih serius, dan juga, mendorong para guru untuk meningkatkan praktik pengajaran mereka.

Dampak positif lain dari ujian nasional adalah untuk menetapkan standar pendidikan di seluruh wilayah Indonesia. Ujian yang dilakukan cenderung bervariasi dari satu sekolah ke sekolah lainnya, dan lebih jauh lagi, terdapat kecenderungan hubungan antara para siswa dan guru untuk mempengaruhi evaluasi akhir sekolah (National Research Council, 2002). Mungkin bagi beberapa orang ujian nasional masih dianggap tidak begitu perlu dilaksanakan. Namun, ujian nasional selama ini dapat memberikan informasi kepada para pemangku kepentingan pendidikan yang memungkinkan mereka untuk meningkatkan kualitas sekolah diIndonesia, dan juga berpotensi dapat digunakan sebagai alat perbandingan dalam hal menganalisis kompetensi dan kualitas siswa, guru serta sekolah itu sendiri. Hal ini dimungkinkan karena ujian nasional dilakukan secara nasional dan oleh lembaga-lembaga eksternal diluar sekolah, sehingga hasilnya pada umumnya lebih dapat diandalkan, karena metode penilaian menggunakan pendekatan evaluatif yang serupa di semua sekolah di seluruh Indonesia.

Tidak hanya memberi dampak positif, ujian nasional juga bisa dikatakan berdampak negatif. Seperti disebutkan di atas, ujian nasional dapat menghasilkan motivasi bagi para siswa untuk belajar lebih serius, dan para guru dapat dibimbing untuk mengajar dengan lebih baik, tetapi dalam beberapa hal, keadaan seperti ini terkesan menipu. Dengan kata lain, para guru hanya mengajarkan para 
siswanya untuk menghadapi ujian saja (Darling-Hammond, 2000). Misalnya, sebagian besar tugas kelas para siswa hanya terfokus pada bagaimana untuk menjawab pertanyaan pilihan ganda seperti yang akan mereka hadapi di ujian nasinal. Karena ujian nasional dirancang untuk menilai keterampilan kognitif dasar, sehingga persiapan untuk ujian nasional seringkali dianggap memiliki terlalu banyak penekanan pada penghafalan konten dan latihan soal, sehingga para guru akan lebih sering menginstruksikan latihan disetiap kesempatan sebagai metode utama dalam proses belajar mengajar (Shepard, 2005). Oleh karena itu, para guru juga akan menggunakan model pengajaran yang praktis dan dangkal demi meningkatkan proses pembelajaran siswa. Dengan demikian, hanya sedikit dari para siswa yang nantinya akan mencapai keterampilan berpikir kognitif tingkat tinggi - seperti berpikir kritis, analisis, dan pemecahan masalah, yang faktanya sangat kemampuan tersebut sangat diperlukan di era sekarang.

Berikut adalah contoh pertanyaan dari Ujian Nasional Bahasa Inggris yang diambil dari Badan Standar Nasional Pendidikan (2014):

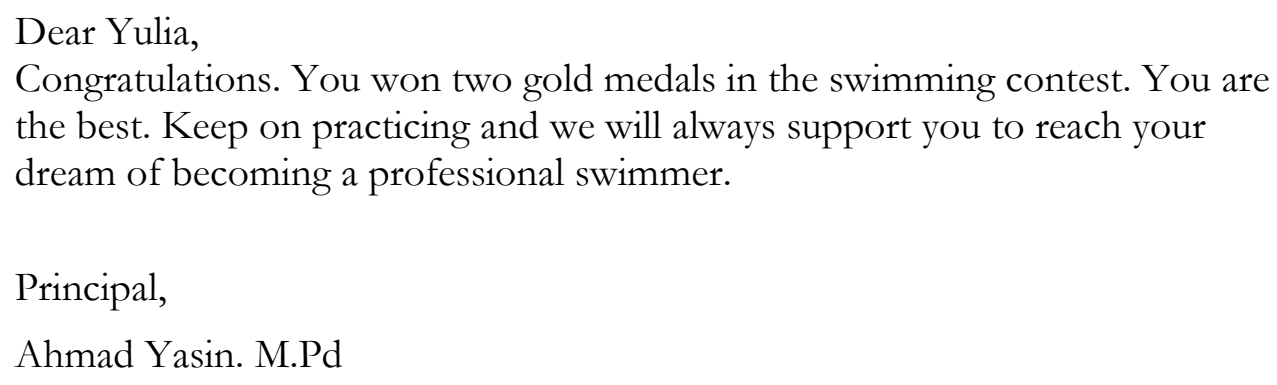

Tabel 1.

Teks di atas adalah untuk pertanyaan nomor 2 dan 3

\section{What is the purpose of the text?}

A. To ask people to support Yulia.

B. To congratulate Yulia on her success.

C. To inform people about the best swimmer.

D. To motivate Yulia to be a professional swimmer.

\section{What expression does the principal use to praise Yulia?}
A. Congratulations.
B. You are the best.
C. Keep on practising.
D. Be a professional swimmer.

Dari contoh pertanyaan ujian nasional bahasa Inggris yang diilustrasikan di atas, berdasarkan pengamatan penulis terhadap proses belajar mengajar dikelas persiapan ujian nasional bahwa kebanyakan guru mengambil pendekatan latihan dan praktek dalam upaya membantu siswa mereka memahami bagaimana 
mengenali genre teks dan fitur-fitur utama pada soal ujian nasional. Jenis pertanyaan semacam ini tidak bertujuan untuk mengajarkan siswa bagaimana berpikir kritis, tetapi hanya meminta siswa untuk menjawab dengan hanya melihat fitur teks dan pola soal.

Kelemahan lain dari ujian nasional adalah cara guru mengajar bahasa Inggris (dan mengembangkan materi Bahasa Inggris) di kelas cenderung terfokus secara sempit. Dengan kata lain, para guru lebih cenderung menggunakan bahan ajar yang akan diuji, daripada menemukan sumber materi yang mendukung kompetensi kurikulum yang lebih luas. Hal ini dikarenakan terdapat tekanan untuk mendapatkan nilai ujian yang tinggi untuk beberapa mata pelajaran, sehingga dapat mempersempit materi bahan ajar yang dibahas di kelas (Madaus pada National Research Council, 2002). Alderson dan Wall dalam Ghorbani, Samad, Hamzah \& Noordin (2008) menyatakan hipotesis washback tampaknya mengasumsikan bahwa karena ujian, para guru dan peserta didik memilih kegiatan yang seharusnya tidak perlu mereka lakukan. Biasanya Kementerian Pendidikan Indonesia akan memberikan kepada setiap sekolah semacam daftar kompetensi dasar kelulusan dari apa yang akan diuji dalam ujian nasional. Sehingga, sebagian besar guru bahasa Inggris yang mengajar di kelas persiapan ujian nasional akan mengabaikan kompetensi bahasa Inggris dasar yang seharusnya terdapat dikurikulum, terutama yang berkaitan dengan kemampuan speaking, dikarenakan kemampuan speaking tidak akan diujikan didalam ujian nasional, namun kompetensi tersebut terdapat didalam kurikulum pembelajaran Bahasa Inggris di kelas 12 sekolah menegah atas. Taylor (2005) mengemukakan bahwa strategi guru seringkali dapat dipengaruhi oleh target siswa mereka yang akan menghadapi ujian tertentu (dalam kasus ini ujian nasinal), dan mereka akan dengan mudahnya menyesuaikan metode pengajaran dan isi pelajaran yang nantinya akan diarahkan pada materi ujian tersebut. Dengan demikian, ada kecenderungan kuat bagi guru dan siswa untuk mengabaikan kompetensi dasar yang tercantum dalam kurikulum.

Dampak negatif dari ujian nasional juga dapat dirasakan dalam buku atau modul bahan ajar yang digunakan para guru untuk mengajar, yang cenderung berorientasi pada ujian nasional. Isi buku yang disediakan terlalu fokus pada bagaimana menjawab pertanyaan ujian nasional, dan dapat dikatakan gagal memenuhi kebutuhan belajar mengajar bahasa Inggris yang berhubungan dengan kompetensi dasar atau tujuan dari kurikulum yang ada. Ujian nasional pada dasarnya diterapkan untuk mendorong sebuah perubahan, dan dalam kasus ini, buku bahan ajar harus dapat menyesuaikan dengan tujuan tersebut (Cheng, 1997). Di Indonesia, buku teks bahan ajar umumnya diterbitkan untuk mendukung proses ujian nasional. Dengan demikian, dapat juga dikatakan bahwa ujian nasional telah mendorong kecenderungan para penerbit untuk menghasilkan buku yang dirancang demi mendukung proses ujian nasional, 
daripada kompetensi menerapkan proses pembelajaran yang seharusnya. Belum lagi jika persoalan tersebut kembali diperluas keranah penyelenggaraan. Isu- isu kecurangan dalam peneyelenggaraan ujian nasional setiap tahunnya selalu berhembus (Alawiyah, 2015). Menurut Novitasari (2011) kecurangan yang dilakukan dalam pelaksanaan ujian nasional disebut juga dengan kecurangan akademis. Kecurangan akademis merupakan semua tindakan curang atau tidak jujur dalam kaitannya dengan upaya untuk meningkatkan prestasi akademis seorang siswa.

\section{Metode Penelitian}

Untuk menjawab pertanyaan penelitian, penelitian ini menggunakan studi tinjauan literatur naratif, yang meninjau kritik dan merangkum isi literatur, lalu menarik kesimpulan tentang pertanyaan topik (Cronin, Frances dan Michael, 2008). Mereka juga berpendapat bahwa tujuan utama dari metode ini adalah untuk memberikan latar belakang yang komprehensif bagi para pembaca untuk memahami pengetahuan terbaru dan menekankan pentingnya penelitian baru (Cronin, Frances dan Michael, 2008).

\section{Hasil Penelitian dan Pembahasan}

Pada bagian hasil studi, penulis menyajikan relevansi untuk menggambarkan beberapa area yang terkena dampak dari ujian nasional berdasarkan penelitian yang ada dan juga berdasarkan pengalaman penulis sendiri, baik sebagai guru maupun siswa. Menurut penelitian yang dilakukan oleh Sukyadi dan Mardiani (2011) pada siswa kelas dua belas (16 tahun), area spesifik yang dipengaruhi oleh studi untuk ujian nasional mata pelajaran Bahasa Inggris adalah kegiatan pengaturan waktu beraktivitas, bahan ajar, metode pengajaran, dan perasaan. Poin pertama, yaitu pengaturan waktu dan kegiatan kelas seringkali dipengaruhi oleh ujian nasional. Sekolah dan para guru umumnya mengubah kegiatan kelas mereka dan mengalokasikan lebih banyak waktu untuk mempersiapkan ujian nasional daripada mengajar kompetensi umum dalam bahasa Inggris (seperti kelas bahasa Inggris pada umumya yang mengajarkan kemampuan speaking, listening, reading dan writing). Hal ini juga terjadi dikarenakan keterbatasan waktu mereka dalam mengajar, sehingga perencanaan penjadwalan tidak bisa diatur dan disesuaikan antara proses belajar mengajar seperti biasanya yang mengajarkan berbagai kompetensi yang sesuai dengan kurikulum, dan pembelajaran yang bertujuan untuk mempersiapkan para siswa dalam menghadapi ujian nasional.

Kejadian ini juga juga dialami penulis ketika masih duduk sebagai siswa sekolah menengah pertama. Dalam hal ini, kegiatan belajar mengajar dikelas lebih cenderung bertujuan sebagai sarana persiapan ujian, daripada menjalani pembelajaran yang bertujuan untuk mengajarkan kompetensi bahasa Inggris berdasarkan kurikulum yang ada. 
Ketika penulis telah menjalani peran sebagai seorang guru, kami juga menyadari bahwa meskipun kami harus menyampaikan materi berdasarkan kurikulum, namun kami juga tetap perlu mengajar semua bahan demi mempersiapkan para siswa untuk menghadapi proses ujian nasional, dan dari proses yang telah dijalani, kami tidak memiliki waktu dan konsentrasi yang cukup untuk melakukan keduanya secara bersamaan. Menurut Bailey (1999) secara umumnya, para guru cenderung melewatkan materi yang selayaknya diajarkan kepada para siswanya untuk fokus pada ujian. Hal ini juga didukung oleh statement Pizarro (2009) yang menyatakan bahwa memberi lebih banyak waktu kepada siswa untuk mempersiapkan untuk ujiannya dengan keterampilan yang berfokus pada menjawab soal- soal latihan, memang diperlukan.

Namun, penelitian lain yang dilakukan oleh Virgo (2016), menunjukkan bahwa guru di beberapa sekolah menengah di Indonesia merasa bahwa mereka pada kenyataannya, memiliki cukup waktu untuk mempersiapkan ujian nasional dan mengajar kurikulum yang ada. Sebagai sumber studi lapangan, peneliti mewawancarai empat guru bahasa Inggris yang bekerja di empat sekolah berbeda. Sebagian besar dari mereka percaya bahwa terkait pengaturan waktu dan kegiatan belajar mengajar dikelas, para guru tidak merasa menekankan para siswanya pada persiapan ujian nasional. Sudut pandang ini mungkin telah tercapai karena para guru ini memberikan penekanan khusus pada penyampaian materi pada semester pertama, dan pada fokus pada persiapan ujian nasional pada semester kedua. Oleh karena itu, dapat disimpulkan bahwa dampak pada manajemen waktu yang baik dan implementasi yang baik dapat dikurangi tergantung pada bagaimana para guru dan sekolah yang bersangkutan dapat mengatur perencanaan mereka untuk mempersiapkan para siswanya dalam menghadapi Ujian Nasional Bahasa Inggris serta mengajar kompetensi Bahasa Inggris berdasarkan kurikulum yang berlaku.

Bagian lain yang terkena dampak dari ujian nasional adalah materi pengajaran yang digunakan. Sukyadi dan Mardiani (2011) menemukan bahwa sebagian besar guru mengadaptasi bahan ajar bahasa Inggris mereka dari buku teks bahasa Inggris ke pertanyaan tipe ujian. Mereka kemudian berlatih bagaimana menjawab pertanyaan ujian nasional dengan melakukan soal ujian yang telah digunakan ditahun- tahun sebelumnya, sehingga para siswa memiliki kesempatan untuk berlatih menggunakan format yang mendekati ujian nasional yang sebenarnya (Shohamy, 2014). Kegiatan ini diyakini sangat efektif oleh para guru bahasa Inggris, termasuk oleh penulis, yang juga mengadopsi pendekatan yang sama. Berdasarkan pengalaman penulis, berlatih soal-soal yang diadaptasi berdasarkan format yang keluar ditahun - thaun sebelumnya secara intens memungkinkan para siswa untuk menjadi lebih akrab dengan pola soal ujian dan pada akhirnya akan lebih dapat lulus ujian dengan sukses. Namun, berdasarkan keterangan dari wawancara penulis dengan para guru dan berdasarkan 
pengalaman penulis sendiri, memang harus diakui hal ini dapat membuat para pengajar menjadi sedikit lalai untuk mengajarkan kompetensi bahasa Inggris yang telah dijabarkan dalam kurikulum karena lebih berfokus pada persiapan ujian nasional.

Dalam prakteknya, metode pengajaran yang digunakan juga seringkali dipengaruhi oleh kebutuhan para guru guna mempersiapkan para siswanya dalam menghadapi ujian nasional. Hal ini dikarenakan para guru dan siswa memiliki waktu yang terbatas, dan juga karena bahan ajar yang tersedia umumnya berbasis persiapan ujian nasional. Oleh karena itu, cara guru melakukan perubahan kelas dapat dikatakan didasari atas penyesuaian kebutuhan yang ada dalam bentuk pembahasan secara ulang pertanyaan-pertanyaan ujian nasional yang telah diujikan ditahun- tahun sebelumnya serta membahas topiktopik yang sering muncul dalam Ujian Nasional Bahasa Inggris sesuai dengan hasil dari kajian dari Sukardi dan Mardiani (2011) dan Virgo (2016), lalu dikonsolidasikan dengan pengalaman yang telah dirasakan oleh para penulis.

Area terakhir yang terindikasi terkena dampak dari ujian nasional adalah perasaan dan sikap para siswa beserta guru. Berdasarkan studi dari Jones, Jones dan Hargrove (2003), tes berisiko tinggi seperti Ujian Nasional Bahasa Inggris dapat memaksa para guru dan siswa (terutama yang dari sekolah yang memiliki reputasi bergengsi) untuk mempertahankan pencapaian tinggi yang sebelumnya telah didapat demi memastikan dan menjaga jumlah siswa yang lulus ujian pada level yang baik. Dengan demikian berdasarkan studi ini, dapat menempatkan guru dan siswa di bawah tekanan besar untuk mengulangi kesuksesan yang sama, karena sekolah bersikeras bahwa hasil siswa harus lebih baik atau paling tidak dapat sama seperti tahun-tahun sebelumnya. Meskipun demikian, temuan berbeda yang ditemukan dalam penelitian Sukaydi dan Mardiani (2011) (berdasarkan dari pengamatan tiga sekolah) mengungkapkan bahwa terdapat satu sekolah yang tampaknya memiliki pendapat yang berbeda. Para siswa di sekolah ini menyatakan bahwa Ujian Nasional Bahasa Inggris tidak membebani atau tidak membuat mereka bingung, dibandingkan dengan dua sekolah lainnya di mana para siswa merasa terintimidasi oleh Ujian Nasional Bahasa Inggris. Bahkan pihak sekolah mengakui bahwa penilaian standar dapat memotivasi siswa untuk belajar lebih keras. Penulis menganggap situasi seperti ini merupakan sesuatu yang tidak biasa. Sebaliknya, di satu sekolah tempat penulis bekerja, para siswa tampak sangat khawatir dengan ujian nasional yang akan mereka hadapi. Namun, dapat dikatakan bahwa washback dari ujian nasional di daerah ini dapat menjadi positif, karena dapat membuat siswa menjadi lebih termotivasi.

\section{Kesimpulan}

Meskipun Ujian nasional secara umum untuk beberapa waktu telah digunakan dalam mengukur kompetensi siswa dan kualitas sekolah, itu masih 
menimbulkan kontroversi. Menurut sebuah makalah yang diterbitkan oleh Badan Standar Nasional Pendidikan (2009), efek washback positif dan negatif dari ujian nasional.

Berdasarkan hasil kajian penelitian serta pengalaman penulis, dapat disimpulkan bahwa Ujian Nasional Bahasa Inggris tampaknya memiliki lebih banyak efek negatif bila dibandingkan dengan efek positifnya. Selain itu, terdapat juga lima area utama yang dipengaruhi secara langsung oleh ujian nasional Bahasa Inggris yaitu pengaturan waktu/kegiatan, bahan ajar, metode pengajaran, dan perasaan para siswa. Secara keseluruhan, terkait pengaturan waktu/kegiatan, metode dan bahan pengajaran seringkali diubah dan disesuaikan dengan kondisi ujian nasional, sehingga lebih terfokus pada persiapan ujian nasional Bahasa Inggris dan implikasikasinya adalah dapat merugikan pengembangan kompetensi bahasa Inggris secara umum (terutama terkait dengan kemampuan dasar bahasa Inggris secara umum; speaking, listening, reading dan writing). Jika dapat dikatakan bahwa metode yang telah dilakukan oleh para guru dalam proses belajar mengajar dengan fokus persiapan ujian nasional Bahasa Inggris adalah lebih cenderung menekankan para keterampilan reading. Hal ini tidak bisa dipungkiri karena sebagian besar soal- soal pada ujian nasional didasarkan pada pemahaman teks. Namun demikian, tidak semua sekolah menganggap ujian nasional sebagai beban. Kemungkinannya dikarenakan lembaga-lembaga ini memiliki perencanaan yang memadai, guru yang berkualitas, serta fasilitas yang diperlukan. Jelas, peningkatan kelas bahasa Inggris untuk semua siswa harus dilakukan, terlepas dari tingkat pendidikan atau sekolah mereka. Hal ini, tentu saja, membutuhkan dukungan dari para pemangku kepentingan utama di Indonesia, terutamanya adalah pemerintah yang menangani bidang pendidikan menengah. Berdasarkan hasil dari studi didalam artikel ini, penulis merekomendasikan kepada pihak dan unsur terkait bahwa ujian nasional tingkat sekolah menengah pertama (SMP) terutama pada subyek Bahasa Inggris agar dapat dirancang ulang secara matang dan efektif yang nantinya berorientasi pada pengukuran kompetensi siswa yang cakupannya dapat lebih luas, objektif, dan berlandaskan penilaian pendidikan karakter, misalnya dengan merancang ujian nasional Bahasa Inggris yang tidak hanya berpatokan pada soal- soal yang diadaptasi dari buku yang berasal dari luar negeri, namun dapat juga mengedepankan unsur serta konteks kearifan lokal Indonesia yang hal tersebut harus diawali dengan penyesuaian kurikulum pengajarannya sehingga tujuan pendidikan Negara Indonesia yang sebenarnya yaitu yang didasari oleh nilai Pancasila dan Undang- undang dasar 1945 dapat segera tercapai.

\section{Daftar Pustaka}

Alawiyah, F. (2015). Perubahan kebijakan ujian nasional (studi pelaksanaan ujian nasional 2015). Jurnal Aspirasi, 6(2), 189-202 
Amengual-Pizarro, M. (2009). Does the English Test in the Spanish university entrance examination influence the teaching of English?. English Studies, 90(5), 582-598

Anggraeni, D. (2015). Dampak Kebijakan Ujian Nasional terhadap Pengembangan Kurikulum Matematika Program Keahlian Tata Busana di SMK Negeri 3 Probolinggo. Jurnal Kebijakan dan Pengembangan Pendidikan, 3(1)

Bailey, K. M. (1999). Washback in language testing. Princeton, NJ: Educational Testing Service

Brown, H. D. (2004). Language assessment principles and classroom practice. NY: Pearson Education

Cheng, L., \& Watanabe, Y. (Eds.). (2004). Washback in language testing: Research contexts and methods. Routledge

Cheng, L. (2005). Changing language teaching through language testing: A washback study (Vol. 21). Cambridge University Press

Cheng, L. (1997). How does washback influence teaching? Implications for Hong Kong. Language and education, 11(1), 38-54

Cheng, L., \& Curtis, A. (2012). Test impact and washback: Implications for teaching and learning. Cambridge guide to second language assessment, 8995.

Cronin, P., Ryan, F., \& Coughlan, M. (2008). Undertaking a literature review: a step-by-step approach. British journal of nursing, 17(1), 38-43

Darling-Hammond, L. (2000). Teacher Quality and Student Achievement. education policy analysis archives. URL http://epaa. asu. edu/ojs/article/view/392

Daryanto. 2007. Evaluasi Pendidikan. Jakarta: Rineka Cipta

Effendi, T., \& Suyudi, I. (2016, November). The Impacts of English National Examination in Indonesia. In Ninth International Conference on Applied Linguistics (CONAPLIN 9). Atlantis Press

Fulcher, G., \& Davidson, F. (2007). Language testing and assessment. New York: Routledge

Furaidah, F., Saukah, A., \& Widiati, U. (2015). Washback of English national examination in the Indonesian context. TEFLIN Journal, 26(1), 36-58

Ghorbani, M. R., Samad, A. A., Hamzah, M. S. G., \& Noordin, N. (2008). The Washback Impact of the Iranian University Entrance Examination on Pre- 
University English Teachers. The Journal of AsiaTEFL, 5(3), 1-29

Hadi, S. (2014). Ujian nasional dalam tinjauan kritis filsafat pendidikan pragmatisme. Al-Adzka: Jurnal Ilmiah Pendidikan Guru Madrasah Ibtidaiyah, $4(2)$

Jones, M. G., Jones, B. D., \& Hargrove, T. Y. (2003). The unintended consequences of high-stakes testing. Rowman \& Littlefield

Kemendiknas, R. I. (2006). Standar Isi untuk Satuan Pendidikan Dasardan Menengah: Standar Kompetensi dan Kompetensi Dasar SD/MI

Nasional, Badan Nasional Standar Pendidikan. (2014). Peraturan Badan Standar Nasional Pendidikan Nomor 0027. Vol. 215. P/BSNP/IX/2014 tentang Kisi-Kisi Ujian Nasional untuk Satuan Pendidikan Dasar dan Menengah Tahun Pelajaran 2014.

National Research Council. (2002). Investigating the influence of standards: A framework for research in mathematics, science, and technology education. National Academies Press.

Novitasari, I. (2012). Sindikasi Jual-Beli Kunci Jawaban Ujian Nasional 2010 (Studi Kasus Jaringan Jual-Beli Kunci Jawaban Ujian Nasional 2010 di Kota X). Jurnal Kriminologi Indonesia, 7(2).

Nugroho, R. (2011). Public Policy: Dinamika Kebijakan, Analisis Kebijakan, Manajemen Kebijakan. Jakarta: Elex Media Komputindo.

Sanjaya, W. (2008). Kurikulum Dan Pembelajaran (Teori \& Praktek KTSP). Kencana. Jakarta.

Shepard, L. A. (2017). Formative assessment: Caveat emptor. In The future of assessment (pp. 279-303). Routledge

Shohamy, E. (2014). The power of tests: A critical perspective on the uses of language tests. Routledge.

Spratt, M. (2005). Washback and the classroom: The implications for teaching and learning of studies of washback from exams. Language teaching research, 9(1), 5-29.

Sundayana, W., Meekaeo, P., Purnawarman, P., \& Sukyadi, D. (2018). Washback of English national exams at ninth-grade level in Thailand and Indonesia. Indonesian Journal of Applied Linguistics, 8(1), 167-176.

Sukyadi, D., \& Mardiani, R. (2011). The washback effect of the English national examination (ENE) on English teachers' classroom teaching and students' learning.k@ ta lama, 13(1),96-111. 
52 | TADBIR : Jurnal Studi Manajemen Pendidikan, Vol. 4, No. 1, Mei 2020

Tsagari, D. (2007). Review of Washback in Language Testing: What Has Been Done? What More Needs Doing? Retrieved May 30, 2017, from https://files.eric.ed.gov/fulltext/ED497709.pdf. 